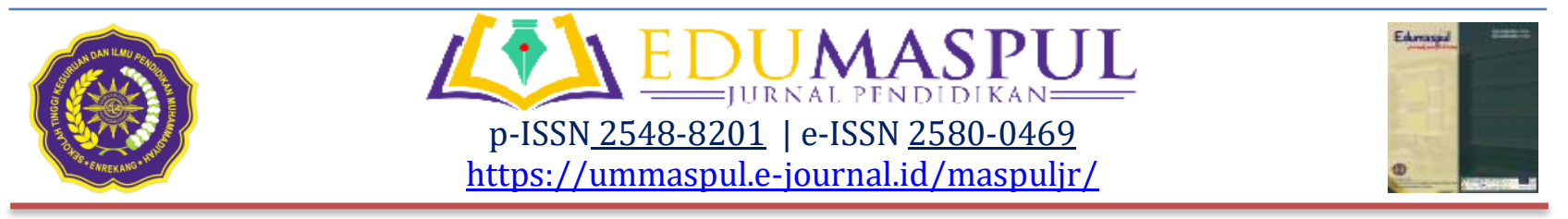

\title{
Career Guidance and Introduction Services Career Students in SMKN 1 Enrekang
}

\author{
Handayani Sura1, Mulyadi² \\ ${ }^{1,2}$ Counseling Guidance Department, STKIP Muhammadiyah Enrekang, Indonesia \\ $\bowtie$ Corresponding email: 1handayanisura7@gmail.com, ${ }^{2}$ muliyadibk@gmail.com
}

\begin{abstract}
Receive: 21-09-2019
Accepted: 01-10-2019

Published: 05-10-2019

Abstract. The implementation objective of this research that was to find out how to service the guidance of a career and the introduction of career students in SMK 1 Enrekang. The method of this research that was qualitative with the subject of research that was the students in SMK 1 Enrekang. The results of research which based on the data results of the questionnaire service guidance career for choice of career showed that the importance of information about the type of work that was useful (40\%) until (60\%) strongly agrees. Consider interest (80\%) strongly agree. Information world of work and the media type of the job (90\%) highly agree. Jobs that require expertise (75\%) strongly agree. The work of entertaining the crowd (60\%) strongly agrees. Lacks of understanding the influence of education (60\%) strongly agree, (35\%) agree. Difficulty channelling hobbies (70\%) strongly agree. Confused determine the school continued conformity ability (90\%) highly agree While the data relationship introductions career against the choice of career showed the percentage of the will of the parents (50\%) less agree. Work activities verbal such as lawyers (50\%) did not agree. Work activities expression of self and creation (70\%) did not agree. So it could be concluded that $60 \%$ of students who chosen the service guidance of a career that was implemented in the school had the benefit important for students and $80 \%$ of students who agree to be holding introductory career to give referrals.
\end{abstract}

Keywords: Guidance career, service career, the introduction of career.

\section{INTRODUCTION}

Education in Indonesia has a purpose, namely the intellectual life of the nation and develop human whole. It is in direct and together become the cornerstone directions service guidance and counseling in schools. Guidance career is one of the aspects of guidance counseling as a whole because it is less wise when implementing the guidance of a career that apart from the guidance of a career as a whole so that the guidance of others abandoned.

Guidance career at the school help the students to know and develop the potential of a career that owned the students. In addition, the guidance of a career is unitary process guidance has benefits for the participant students in directing ourselves and create independence in choosing careers that suit their ability. Therefore, it is expected to able to cope with problems such as lack of 
understanding ourselves on students and less recognition themselves choose a career that is experienced within themselves the students to be able choose a job and resume a career .

Service counseling career is activity and service assistance for students with the purpose to obtain the adjustment themselves, an understanding of the world of work and in the end were able to determine the choice of work and draw up plans career.

Guidance career as a means revamping needs for the development of individuals who should be seen as part of an integral of a program of education which in integrated into every experience the field of study. Guidance careers associated with developments in realizing the concept of self that is positive, understanding the process of decision making as well as the acquisition of knowledge and skills that will help him enter life, grammar live from events in life that continues to constantly change, are not solely limited to the guidance office or guidance tasks .

Based on the results of research by (Hasnidar, 2018) proved that the guidance career affect quite significantly against the independence of the students in choosing a career can be concluded there is influence positively the significant service information guidance careers of students in improving the independence of choosing the career of students. By thus can be explained that the service guidance career needs to be given to the students to filter and select potential which is owned by the student in determining his choice to embody him on the job or office or careers that will be taken later in the day .

The provision of career guidance services at schools is carried out to equip students with knowledge in the field of school education, in the field of work, and social personal development. So that students are able to organize and plan their own lives. As a result of the provision of services guidance, can impact on the introduction of the career of students and the selection of careers that are less precise. One of the bad effects, students will be confused in determining further study options to Higher Education (Yasdar \& Mulyadi, 2018). So also with the students who decide to work after graduating high school, students will be confusion choose jobs which are appropriate to the circumstances themselves.

Based on the results of observations directly researcher at SMK 1 Enrekang, which is located in the sub district alla Enrekang regency, researcher and teacher guidance and counseling, perform the guidance of a career and the introduction of the career of the students, which is marked by the results of research that shows the data results of the questionnaire service guidance career and recognition career, choice of career shows that the importance of information about the type of work that is useful (40\%) until $(60 \%)$ strongly agree. Consider interest (80\%) strongly agree. Information world of work and the media type of the job (90\%) highly agree. Jobs that require expertise $(75 \%)$ strongly agree. The works of entertaining the crowd (60\%) strongly agree. Less understands the influences of education (60\%) strongly agree, (35\%) agree. Difficulty channeling hobbies (70\%) strongly agree. Confused determine the school continued in accordance capability (90\%) highly agree. While the Data relationship introductions career against the choice of career shows the percentage of the will of the parents (50\%) less agree. Jobs that require expertise, strength and organization (90\%) strongly agree. Considering gifted in the choice of majors (50\%) strongly agree. Work involves 
cognitive activities (70\%) strongly agree. Data of jobs that involve the activities of inter- personal (70\%) highly agree. Following the enlightenment about the ins and outs of the world of work (80\%) strongly agree. Works structured and organized as accounting (60\%) did not agree. Work activities verbal such as lawyers (50\%) did not agree. Work activities expression of self and creation $(70 \%)$ did not agree. So it can be concluded $60 \%$ of students who choose that service the guidance of a career that is implemented in schools has benefits important for students and $80 \%$ of students who agree to be holding introductory career to provide referrals for students in the election program of study or work.

\section{METHOD}

The type of this research was qualitative. Research qualitative was research that was carried out based paradigm, strategy, and implementation of the model. The perspectives, strategies and models developed were very diverse. Qualitative methodology was defined as a research procedure that produces data descriptive form of words written or spoken of people and behaviors that could be observed.

In legal research qualitative is the collection of data on a background of nature, by using the method of nature, which is carried out by people or researchers who are interested in nature. Author others also defines research qualitative is research that uses the approach naturalistic to seek and find acceptance or understanding in a setting that is contextual special (Lexy J. Moleong, 2005).

The type of research this was a study of qualitative. The purposes of this study were to know the application of service guidance career and introduction of career students in SMK 1 Enrekang".

Instrument Research was used recorded reactions and participation students during the implementation of the provision of service information, through observation was direct. The aspects were observed was participation, tolerance, attention, and initiative. How users with a way to give mark $(\sqrt{ })$ in every aspect that appears. Questionnaires were used in distributed to students. The interview was a conversation with a purpose specified by the two parties, namely the interviewer as filing/giver of questions and were interviewed as answer provider to that question (Lexy J. Moleong, 2005).

According to Moleong (2002) data analysis technique is the process of sequencing data, organizing into a pattern, category and basic unit description. A very important stage in a research is data analysis. The process of analysis of the data begins with examining the entire data available from various sources of information; the results of the observations are recorded in the field, and documentation (Moleong, 2002). The analysis consists of three groove activity which consists in simultaneously, namely: the reduction of data, presentation of data, withdrawal, and verification. Steps were taken, namely: 1). Collection of data, on the stage of this research to collect the data from the results of observations, observation, interviews, and documentation. 2). Reduction, namely the election of attention on simplification, and transformation of data rude that emerged from the notes written in the field. The data was reduced that the data results of observations and interviews in the form of a questionnaire which form a picture application service guidance career against the introduction of career 
students. 3). Presentation of data, which was a collection of organized information that gives the possibility of drawing conclusions and taking action. Presentation of data carried out by means of descriptive that is based on aspects of the investigation. The data presented are data relationship counseling career against the introduction of the career of students.

\section{RESULTS AND DISCUSSION}

Analysis of the data interviews were used in research this is an interview structured by using the guidance interview. Interviews conducted by intensively with teacher guidance counseling at SMKN 1 Enrekang. Interviews are held on the Monday 14 August 2018 in room BK, to determine the application of service guidance career and the introduction of a career in SMK 1 Enrekang.

According to the counseling guidance teacher at SMK 1 Enrekang that previously Provision of information about school selection, study programs, higher education or work had been done at SMK 1 Enrekang. Provision of this information was very important for students, especially for students of class XII who want to continue their studies. As that proposed by the teacher BK as follows:

\section{"Of course a very important and necessary for the students, especially in high school or vocational school, because very in need by the students, especially students class XII who wish to study or work in a place."}

Opinions that could be concluded that the previous teacher guidance counseling ever did guidance for students, in addition to the BK teachers also provided information about election work in SMK 1 Enrekang done by formal in the classroom. If there are hours of lessons BK or hour lessons are empty and if there are students who are less aware of the information that is conveyed students can come into the room BK to ask for information to the Master BK. Such as that proposed by the teacher BK as follows:

"I convey the information that is formal in class, because all students must have need of all the information that when there are hours of lessons $B K$ or when there are hours of lessons were empty. When students were less understood, could come directly for chamber BK and ask for information that was submitted".

All the information that is conveyed by the teacher BK is very important for the students, because it could give an idea or view of the students want to continue where directions after the finish and add insight into the students. As that expressed by teachers BK as follows: "Yes, of course a very important one because of things that can add insight into the students".

The role of the BK teacher in career counseling guidance is to provide assistance and direction for students in the selection of study programs, Higher Education or Employment. The role of the BK teacher also provides information about the program of study, Higher Education and employment. As that expressed by teachers BK as follows:

"Master BK only as informants and just give rock or referrals for students in the election program of study, University High or work".

In addition to the provision of information about the selection of schools, 
programs of study, university or job counseling teacher also should provide an understanding of self, environment and so on to the students so that students can know the capability that is owned. As that expressed by teachers BK as follows:

"Never, especially information about understanding ourselves because, to know how far the ability of students to understand ourselves alone".

The response of students is very pleased with the provision of information about the selection of career or guidance counseling careers are given, because through the information that students can have a view or picture of want where after they graduate school later.

In organizing programs BK career should be held MGBK (Deliberation Teacher Guidance Counseling) that guidance career or guidance were implemented more conducive, as yet there are many teachers BK in the District Enrekang. In schools was much the shortage of teachers BK, so Teachers lesson was involved in BK. Such as that disclosed by BK teachers as follows: "My advised for BK Career Program organizers is the frequent holding of MGBK ( $\mathrm{BK}$ Teachers Deliberation ) in the Enrekang regency so counseling guidance teachers in schools often did career guidance for their students.

Based on the opinion of the above can be concluded that the information about the selection of the School, Program Studies , University High and job ever done in the formal in class, because all students in need of all the information that to add insight and experience of the students . The roles of BK teachers in schools it merely as informants and just give rock or referrals for students in the election program of study, University High or work.
Information about understanding yourself is given to determine how far the ability of students to understand themselves alone. Giving this information for students very happy especially students who will graduate.

\section{Questionnaire Data Analysis}

After the data collected both were associated with the service guidance of a career and the introduction of career students in SMK 1 Enrekang. Then the next process was to analyze the data. As the purpose of the study was that to determine the extent to which the effectiveness of service guidance career and the introduction of career students. Then the researchers analyzed the data as follows:

Analysis of service guidance career at SMK 1 Enrekang to answer the formulation of the problem the first is how:

\section{Career Guidance Services For Students' Career Introduction at SMKN 1 Enrekang}

Based on the data the guidance to know the talent is (0\%) answered very agree, (0\%) answered agree, (60\%) answered less agree, and (40\%) answered do not agree. Then it could be inferred from the data guidance to recognize talents over many who choose less agree as much as $60 \%$ compared with not agree as much as $40 \%$.

The types of work helped establish choice of career after graduating school percentage was $(0 \%)$ answered very agree, (0\%) answered agree, (80\%) answered less agree, and (20\%) answered do not agree. Then it could be concluded from the data types of work helps to set the choice of career after graduating school many who choose less agree as 
much as $80 \%$ compared with not agree as much as $20 \%$.

Information activities are carried out for the kind of work a certain very useful for the stability of choice of career. Based on the data information activities were carried out for the kind of work a certain very useful for the stability of choice of career percentage is (60\%) answered very agree, (40\%) answered agree, (0\%) answered less agree, and (0\%) answered did not agree. So it could be concluded from the data very useful for the stability of career choices that choose strongly agree as much as $60 \%$ compared to agree as much as $40 \%$.

In order to be successful in a career, it is necessary to consider the interest to choose majors in university. Based on the data in order to be successful in a career, it was necessary to consider the interest to choose majors in university, the percentage was (80\%) answered very agree, (20\%) answered agree, (0\%) answered less agree, and (0\%) answered no to agree. So the conclusion from the data in order to be successful in a career, it was necessary to consider the interest to choose Majors University over many who choose extremely agree as much as $80 \%$ compared to agree as much as $20 \%$.

Not too consider whether the chosen majors in accordance with ideals. Based on the results of the research could be concluded that, not too expensive if the majors were selected in accordance with the ideals of the percentage was $(0 \%)$ answered very agree, (50\%) answered agree, (0\%) answered less agree, and $(50 \%)$ answer did not agree. So it could be concluded from the data not too consider whether in the chosen majors in accordance with the ideals that choose to agree as much as $50 \%$ while those who choose to disagree as much as $50 \%$.
Information on the types of jobs that were very useful in determining career choices, based on the results of the study it could be concluded that, the information on the types of jobs that were very useful in determining career choices, the percentage was $(0 \%)$ answered strongly agree, (10\%) answered agreed, (60\%) answered less agree, and (30\%) answered did not agree. Then it could be concluded from the data information about the kinds of jobs that were very helpful in the set choice of career over many who choose less agree as much as $60 \%$ compared with not agree as much as $30 \%$.

Willingness which had become the basis of a consideration in selecting one of the majors' universities then could be concluded from the data willingness had become a basic consideration in choosing one of the majors' universities over many who choose less agree as much as $60 \%$ compared to agree as much as $40 \%$.

Less understand the influence of education with success in career, Based on the result that is obtained then the data on less understand the influence of education with success in career, the percentage is (60\%) answered very agree, (35\%) answered agree, (0\%) answered less agree, and (5\%) answered that they did not agree. Then it could be inferred from the data less understand the influence of education with success in a career over many who choose extremely agree as much as $60 \%$ compared to agree as much as $35 \%$.

Information about strategies to enter further education. Based on the data information on the strategy to enter education continued percentage was $(10 \%)$ answered very agree, (10\%) answered agree, (20\%) answered less agree, and (60\%) answered do not agree. Then it could be inferred from the data information on the strategy to enter the 
education continued over many who choose not agree as much as $60 \%$ compared to agree as much as $10 \%$.

Feeling confused in determining the school continued that according to ability. Based on the results of the study, the data was confused in determining school continuation which according to ability, the percentage was $(90 \%)$ answered very agree, (5\%) answered agree, (5\%) answered less agree, and (0\%) answered do not agree. Then it could be inferred from the data feel confused in determining the school continued that according to ability over many who choose extremely agree as much as $90 \%$ compared with the much less agree as much as $5 \%$.

\section{Analysis of Students' Career Introductions at SMK 1 Enrekang}

Based on the data choosing jobs/careers in accordance with the will of the parents percentage was (10\%) answered very agree, (30\%) answered agree, (50\%) answered less agree, and (10\%) answered do not agree. Then it could be inferred from the data selecting jobs/careers in accordance with the will of the parents over many who choose less agree as much as 50\% compared to agree as much as $30 \%$.

Work physical activities that required expertise, strength and organizational, based on the results of the acquired work activities of the physical that requires skill strengths and organizational percentage was (90\%) answered very agree, (10\%) answered agree, (0\%) answered less agree, and $(0 \%)$ answered do not agree. So it could be concluded from the work data of physical activity that requires strength and organizational expertise, more people who choose strongly agree as much as $90 \%$ compared to agree as much as $10 \%$.
Work involved cognitive activities (thinking, organizing, and understanding). Based on the results of the study then the data work involved the activities of cognitive (thinking, organizing, understanding) the percentage was (70\%) answered very agree, (30\%) answered agree, (0\%) answered less agree, and $30 \%$ ) answered did not agree. So it can be concluded from the work data involving cognitive activities (thinking, organizing, and understanding) more people who choose strongly agree as much as $70 \%$ compared to agree as much as $30 \%$.

Opportunities jobs were available in the community affect it was in choosing the type of career that was selected. Based on the results were obtained, then the data chance of jobs that were available in the community influence in choosing the type of careers that had the percentage was (20\%) answered very agree, (40\%) answered agree, (30\%) answered less agree, and (10\%) answered did not agree . Then it could be concluded from the data chanced of jobs that were available in the community influence in choosing the type of career that had over many who choose to agree as much as $40 \%$ compared with less agree as much as $30 \%$.

Determine the majors to be chosen in higher education based on ideals. Data set majors' universities based on the ideals, the percentage was (40\%) answered very agree, (60\%) answered agree, (0\%) answered less agree, and (0\%) answered did not agree. Then it could be concluded from the data set the department that would have university based on the ideals over many who chosen to agree as much as $60 \%$ compared with the very agree as much as $40 \%$.

Like jobs that involved a lot of feelings like acting, data about liking jobs that involved a lot of feelings like acting, the percentage was $(0 \%)$ answered strongly 
agree, (5\%) answered agreed, (20\%) answered less agree, and (70\%) answer did not agree. Then it could be inferred from the data like a job that many involved feeling like acting over many who chosen not agree as much as $70 \%$ compared with less as much as $20 \%$.

Choosing majors' universities by chance jobs were available in the community. Data choosing majors' universities by chance jobs were available in the community the percentage is (15\%) answered very agree, (20\%) answered agree, (25\%) answered less agree, and (40\%) answered did not agree. Then it could be inferred from the data selecting majors' universities by chance jobs were available in the community over many who chosen not agree as much as $40 \%$ compared to less agree as much as $25 \%$.

Prefers work that involved selfexpression and creative activities. Data about like a job that involved the activities of the expression of self and creations, the percentage was $(0 \%)$ answered very agree, (0\%) answered agree, (45\%) answered less agree, and (70\%) answered did not agree. Then it could be concluded from the data like a job that involved activities expedition themselves and creations over many who chosen not agree as much as $70 \%$ compared with less agree as much as $30 \%$.

Channeling talent that affected the career specific. Data shown the percentage was $(0 \%)$ answered very agree, $(0 \%)$ answered agree, (10\%) answered less agree, and (90\%) answered did not agree. Then it could be inferred from the data channel the talents that affect the careers of certain over many who chosen not agree as much as $90 \%$ compared with less agree as much as $10 \%$.

\section{CONCLUSIONS}

Based on the results of the research can concluded that the services guidance career against the introduction of the career of students held at SMK 1 Enrekang through the provision of information about the selection of schools, programs of study, students of university High that the students are able to choose a career according to his ability. Service counseling career at SMK 1 Enrekang is a service or activity that in given to individuals (students) to be able to know him, a career and choose future ahead that according to his wishes.

The role of BK teachers in the implementation of career guidance services is only as information and to provide assistance or direction for students about their careers going forward. Through the introduction of the career of the students result that the student is able to independently in choosing a career and provide results positively in determining his choice. And based on questionnaires that were distributed to the students obtained the results as follows, namely: $60 \%$ of students SMK 1 Enrekang who agree if implemented service guidance career. Furthermore, 80\% of Enrekang Vocational School 1 students who agree if a career introduction are carried out because it is useful to provide assistance and direction for students in future career selection.

Based on the conclusions on the above, the researcher gives suggestions as follows:

1. Students need to develop planning a career in a way looking for information about careers is kept constant.

2. Teacher mentors in order to better streamline the service guidance and counseling, particularly counseling career to prevent the onset of 
problems are associated with planning a career. Teacher mentors also can create a plan to improve the cooperation with various parties such institutions, universities height or companies that can provide information on the career of students.

\section{REFERENCES:}

[1] Abdul Gani, Ruslan. 1997. Ciri Khas Anak Jenius. Jakarta. Sarana Cipta Ilmu.

[2] Depdiknas, Dirjen Dikdasmen. 2005. Pengembangan Program Bimbingan Konseling SMA. Jakarta. P3G.

[3] Depdiknas, Dirjen Dikdasmen. 2005. Profesi Bimbingan dan Konseling. Jakarta. P3G.

[4] Hasnidar, H. (2018). Pengaruh Pembelajaran Kontekstual Terhadap Hasil Belajar PKN Siswa Kelas VIII SMP Negeri 1 Ulaweng Kabupaten Bone. Edumaspul: Jurnal Pendidikan, 1(1), 42-47. https://doi.org/10.33487/edumasp $\underline{\text { ul.v1i1.39 }}$

[5] Mappiare Andi. 1986. Pisikologi remaja: Surabaya, Usaha nasional

[6] Moleong Lexy J, (2005). Metode penelitian Kualitatif. Bandung: Remaja Rosdakarya

[7] Muliyadi, M., Yasdar, M., \& Sulaiman, F. (2017). Penerapan Teknik Manajemen Diri dapat Mengurangi Kebiasaan Prokrastinasi Akademik Mahasiswa STKIP Muhammadiyah Enrekang. Edumaspul: Jurnal Pendidikan, 1(2), 92-103. https://doi.org/10.33487/edumasp ul.v1i2.43

[8] Prayitno dan Erman Anti. 1999. Dasar-Dasar BK. Jakarta. Rineka Cipta.
[9] Prayitno. 1998. Buku III Seri Pemandu Pelaksanaan BK di Sekolah. Jakarta. Dirjen Dikdasmen.

[10] Sahani, Muchlas, dkk. 1999. Panduan Manajemen Sekolah. Jakarta. Depdiknas Dirjen Dikdasmen.

[11] Siswoharjono, Aryatmi. 1996. Perspektif Bimbingan dan Konseling di Berbagai Institusi. Semarang . Satya Wacana.

[12] Sura, H., Mahyuddin, M., Muliyadi, M., \& Hasnidar, H. (2018). Perilaku Terisolir (Studi Kasu pada Siswa di SMPN Satu Atap 4 Bonggakaradeng). Edumaspul: Jurnal Pendidikan, 2(1), 41-48.

https://doi.org/10.33487/edumasp ul.v2i1.14.

[13] Sukardi, Dewa Ketut. 2000. Pengantar Pelaksanaan BK di Sekolah. Jakarta. Rineka Cipta.

[14] Walgito, Bimo. 2004. Bimbingan Organisasi BK di Sekolah. Yogyakarta. Andi.

[15] Yasdar, M., \& Muliyadi, M. (2018). Penerapan Teknik Regulasi Diri (selfregulation) untuk Meningkatkan Kemandirian Belajar Mahasiswa Program Studi Bimbingan Konseling STKIP Muhammadiyah Enrekang. Edumaspul: Jurnal Pendidikan, 2(2), 50-60. https://doi.org/10.33487/edumasp ul.v2i2.9

[16] Yusuf, Syamsu dan Nurihsan, Juantika. 2005 Landasan Bimbingan dan Konseling. BandungPT.RemajaRo 